\title{
Corrections of the Mahāyānasūtrālamikāra XI. 35
}

\section{Takanori Umino}

The text of the Mahāyānasūtrālamikāra, edited by S. Lévi has played an important role not only in the study of the early Yogacāra philosophy, but also in that of Mahayanic philosophy in general. Above all, the chapter XI, "Dharmaparyeștyadhikāra" is widely noted as the most important chapter for the reason why it intensively expresses the heart of the Yogacāra philosophy of Maitreyanātha himself. As is well known, its position is also regarded as the comparable to that of the Lakṣanapariccheda of the Madhyāntavibhāga. Undoubtedly, the verse of XI. 35, with the preceding verse, that is entitled "Vijñaptimātraparyești" or the investigation of the concept "vijñaptimãtra" is one of the most prominent verses in this chapter because of its reference to the heart of the philosophy. Examining the verse of Lévi's edition, however, we find a numder of strong grounds for doubting the authenticity of the edition. Therefore the purpose of this paper is to compare the text of the edition with the following new manuscripts and to correct the verse. ${ }^{1)}$

Materials and Abbreviations

Mss : Sanskrit manuscripts2)

1) Corrections of the text were already indicated by S. Lévi in his French translation of the text. Prof. Nagao has succeeded to Lévi's business, and elaborated upon his corrections, making out Corrigenda of the Text. The main sources of his corrigenda, however, depend on the Tibetan and Chinese versions and the newly discovered manuscripts of ours are rarely consulted in his works. This paper attempts to achieve more authoritative results, more or less different from the above by means of consulting chiefly the new Sanskrit manuscripts.

2) Mss. A and B were studied by Prof. S. Takeuchi in the Ryukoku Daigaku Ronshu No. 352. His study led up to this one. Moreover, we owe it to the kindness of Mr. G. Tsutsumi, the vice-chief of the Library that we could get these copies. 
Corrections of the Mahāyānasūtrālamikāra XI. 35 (T. Umino)

A : The manuscript preserved in the Ryukoku University Library, Kyoto. 171 leaves, 17 lines $31.2 \times 9.7 \mathrm{~cm}$

B : The manuscript preserved in the Ryukoku University Library, Kyoto. 186 leaves, 91 lines $26.2 \times 12.2 \mathrm{~cm}$

When the verses (XI. 34, 35.) of Lévi's edition are compared with the verses of Mss. A and B, they are as follows. ${ }^{3)}$

(Lévi's edition)

cittam dvayaprabhāsam rāgādyābhāsamiṣyate tadvat/

śraddhādyābhāsam na tadanyo dharmaḥ kliṣṭakuśalo 'sti// 34

cittamātrameva dvayapratibhāsamiṣyate grāhyapratibhāsam grāhakapratibhāsam ca/ tathā rāgādikleśābhāsam tadeveṣyate/ śraddhādikuśaladharmābhāsam vā/ na tu tadābhāsādanyaḥ kliṣṭo dharmo 'sti rāgādilakșaṇaḥ kuśalo vā śraddhādilakṣaṇaḥ/ yathā dvayapratibhāsādanyo na dvayalakșanah/

iti cittam citrābhāsam citrākāram pravartate// 35

tathābhāso bhāvābhāvo na tu dharmāṇām mataḥ/ tatra cittameva vastu taccitraābhāsam pravartate/ paryāyeṇa rāgābhāsam vā dveșābhāsam vā tadanyadharmābhāsam vā/ citrākāram ca yugapat śraddhādyākāram/ bhāso bhāvābhāvaḥ klị̣țakuśalāvasthe cetasi/ na tu dharmāṇām kuśalānām tatpratibhāsavyaatirekeṇa tallakṣaṇabhāvāt/

(Mss. A 68 b 1 68b 7)

cittam dvayaprabhāsam ca rāgādyābhābhāsamișyate tadvat/

śraddhādyābhāsam vā na tu dharmah kliṣțakuśalo 'sti// 34

cittamātrameva dvayapratibhāsamișyate grāhyapratibhāsam grāhakapratibhāsam ca tathā rāgādikleśābhāsantadeveșyate śraddhādikuśaladharmā(bhā)sam vā/ na

3) Oblique lines used for punctuating in Mss. A and B are put on the very place where their editors put punctuation marks. Verses of them are extracted from sentences that are not characterized as the verse, though punctuated, and arranged as stated above. There are no punctuation marks between the former half-verses of XI. 35 and the latter half-verses in Mss. A and B, so we punctuate between them accoring to the verse cited in Vasubandhu's commentary and Sthiramati's of the Tibetan version and the versification of the Anuștubh. The dotted line and the straight line are used for showing the correlation of the passages of Mss. A and $B$ with the passages of Lévi's edition in their content. 
tu tadābhāsādanyaḥ kliṣṭo dharmo 'sti rāgādilakṣaṇaḥ kuśalo vā śraddhādilakṣaṇaḥ/ yathā dvayapratibhāsādanyo na dvayalakșaṇa iti/ cittam citrābhāsam citrākāram pravartate tacca (/) bhāso bhāvābhāvo na tu dharmāṇām atas ta (tra)// 35 cittamevas(?)ca taccitrābhāsam pravartate/ paryāyena rāgābhāsam vā dveșābhāsam vā tadanyadharmābhāsam vā citrākāra(m) ca yugapat śraddhā(d)yākāram bhāso bhāvābhāvaḥ kliṣṭakuśalāvasthe cetasi/ na tu dharmāṇām kuśalānām tatpratibhāsavyatirekena tallakṣaṇābhāvāt/

(Mss. B 62a 2 62b 2)

cittam dvayaprabhāsam rāgādyābhāsamișyate tadvat/

śraddhādyābhāsam na tatra dharmah klișțakuśalo 'sti// 34

cittamātrameva dvayapratibhāsamișyate grāhyapratibhāsam grāhakapratibhāsañca tathā rāgādikleśābhāsantadeveșyate/ śraddhādikuśaladharmābhāsam vā/ na tu tadābhāsādanyaḥ kliṣṭo dharmo 'sti rāgādilakṣaṇaḥ kuśalo vā śraddhādilakṣaṇaḥ̂/ yathā dvayapratibhāsādanyo na dvayalakșana iti/

citta(m) citrābhāsam citrākāram pravartate tacca (/)

bhāso bhāvābhāvo na tu dharmāṇām atas tatra// 35

cittamevasca taccitrābhāsam pravartate/ paryāyena rāgābhāsam vā dveșābhāsam vā tadanyadhrmābhāsam vā citrākārañca yugapat śraddhādyākāram bhāso bhāvaabhāvah klistakuśalāvasthe cetasi na tu dharmāṇām kuśalānāntatpratibhāsavyatirekeṇa tallakṣaṇābhāvāt/

In the above comparison, we may find out that there are a number of differences between Lévi's edition and Mss. A and B, while Mss. A is nearly equivalent to Mss. B in its content. Therefore the textual criticism between both of them should be required as follows.

4) This fragment is illegible also in these manuscripts. Prof. Nagao "vastu tac ci-" of Lévi's edition as "vastutas ci-" in his Corrigenda. We, however, can find out no words equivalent to "vastu" in any texts. For instance, Tibetan translation of this fragment is as follows. sems ḥdi ñid rnam grans kyis ḥdod chags su snan ba ham/ she sdan du snañ ba ham/de las gshan pahi chos su snan ba sna thsogs su snan் ba dan்/ cig char dad pa dan brtson hgrus la sogs pahi rnam pa ste/.....

We would rather change vastu tac ci- into ca tac ci-, because we may suppose that ca tac ci- corresponds to citrābhāsam $\cdots \cdots$... tacca of the verse of XI. 35 . 
1) The textual criticism based on the Sanskrit versification.

Undonbtedly, the meter of XI. 35 in Mss. A and B belongs to the Anuștubh, judging from the number of syllables. The same is applicable also to the meter of the verse of Lévi's edition, to say nothing of the ambiguity of its meaning. (Mss. A and B)

|-- - | - - / - U - $U--\cup / 16$ syllables

|- - - / - U U/ - - U/ U - / 15 syllables

(Levi's edition)

|U-U-/ UU--/ - UU/ U-U - 16 syllables

IU U - / - - / - - / U U U 16 syllables

Strictly speaking, the latter half-verses in Mss. A and B consists of fifteen syllables and the number of syllables in them lacks one sylleble of sixteen syllables, while that of Lévi's edition perfectly keeps to the rule of the Anustubh. On the point of view of the Sanskrit versification, we cannot but conclude that the verse of the edition is superior to that of Mss. A and B. However, that of the edition that is punctuated between "yathā dvayapratibhāsādanyo na dvayalakṣaṇaḥ" and "iti"

5) Examining the syllable or the mora of the verses of the chapter XI, we see the fact that there are a few verses that accurately keep to the rules of the Sanskrit versification. For instance, the verse of XI. 34 does not accurately keep to the rule of the Āryā, though Lévi assigns it to the Āryā. In the Āryā, the first and third quarters must each contain 12 morae or syllabic instants, and the second 18 , and the fourth 15 , so the former half-verses must contain 30 morae, and the latter halfverses 27 , while the former half-verses of Lévi's edition contains 29 morae, and the latter half-verses 28 morae. The verses of Mss. A and B, however, present a striking contrast to the above. It is indisputably evident that they keep to the rule of the Anustubh. They are as follows.

(Lévi's edition)

$|--| U-U|--|--|--| U-U|--| U 29$ morae

$|--|--|-U \cup|--|--|-U \cup \mid U-U / 28$ morae

(Mss. A)

/ - UU/ U- U / - - / U-U-/ $U 18$ syllables

$|----|--\cup \cup /---\cup / \cup \cup-\cup / \quad 16$ syllables

(Mss. B)

/ - U U / U---/ - - U/ -U--/ U 17 syllables

|----| $-U-\cup /---\cup / \cup \cup-U / \quad 16$ syllables 
sounds strange from the standpoint of the sentence structure and the meaning of the verse itself. The above two fragments are not punctuated between each of them in Mss. A and the same example is seen also in the Tibetan translation. We should, accordingly, know that the conformity to the rule does not necessarily shows the authenticity of the verse,5) as is often the case with the Buddhistic versification of those days.

2) The textual criticism on its meaning.

Undoubtedly, the word of "iti" forms a part of Vasubandhu's commentary of XI. 34.6) Therefore the verse of XI. 35 must take on a new meaning different from that of the French translation. The new verse of XI. 35 translates as follows.

The consciousness appears, as though its appearance were something miscelleneous, and a miscelleneous form (ākāra). Their appearance on it exists and yet does not exist. Therefore there is nothing in the categories (dharma), however.

According to the commentaries, the meaning of the verse reads as follows.

The consciousness, appears, as though its appearance were the category of the viciousness (kliștadharma) and that of the meritoriousness (kuśaladharma). Their appearance on the consciousness, however, does exist as a delusion, while it does

6) The whole passage of "yathā dvayapratibhāsādanyo na dvayalakṣaṇa iti" translates as follows.

For instance, as the entity that consists of the subject-object duality does not exist apart from the appearance (of the consciousness) as though two things.

Needless to say, this passage is cited as an instance to add a supplementary explanation to the commentary of the proceding verse. Asvabhāva comments on the above as follows. dper na gñis su snan ba las gshan pa gñis kyi mthsan ñid med pa bshin no shes bya ba ni sems snan ba la ma gtogs ba mig dan/gzugs la sogs pa gzun ba dan ḥdsin paḥi mthsan ñid kyi do dam pa ñid du med pa ltar hạdod chags la sogs pa yan de dan hạdraḥo/

(English translation)

This passage "yathā dvayapratibhāsādanyo na dvayalakṣaṇa iti" means "Just as the entity that consists of the perception (grāhaka) such as the eyesight (cakșus) and the like, and its percept (grāhya) such us the colored object (rüpa) and the like does not exist apart from the appearance of the consciousness, so is the category of the viciousness (kliștadharma) that comprises the attachment (to phenomenal existence and desire for objects of enjoyment) (rāga)." 
not exist because it is only apparent and unsubstantial. Therefore there is no entity in the above categories, which may be regarded as a kind of the noumenon.

Thus examining, we may conclude that the verse of XI, 35 of the edition should be corrected as follows.

…./ yathā dvayapratibhāsādanyo na dvayalakṣaṇa iti/

cittami citrābhāsam citrākāram pravartate tacca/

bhāso bhāvābhāvo na tu dharmāṇām atas tatra// 357)

(昭和 48 年度文部省科学研究費〔総合研究 A〕による研究成果の一部)

7) For reference, Tibetan translation of the verse are as follows.

- (The verse of XI. 35 quoted in Vasubandhu's commentary)

…../ dper na gñis su snan் ba las gshan pa gñis kyi mthsan ñid med pa bshin no//

sems ni sna thsogs snan ba dan/ rnam pa sna thsogs can du hajug/

de la snan ste yod dan med/ de phyir chos kyi ma yin no// 35

(The verse of XI. 35 quoted in Sthiramti's commentary)

sems ñid sna thsogs snan ba ste shes bya ba la/ $35 \mathrm{a}$

sna thsogs pahi rnam pa hjug ces bya ba la/35b

snañ ba dños dan் shes bya ba la/ $35 \mathrm{c}^{\prime}$

dnos med pa shes bya ba la/ $35 \mathrm{c}^{\prime \prime}$

de la chos kyi min shes bya ba la/ $35 \mathrm{~d}$ 